\title{
The antibiotic activity of some Brazilian medicinal plants
}

\author{
Maria R. Ferreira de Lima ${ }^{1}$, Eulália C.P. Azevedo Ximenes', Josiane S. Luna ${ }^{1}$, \\ Antônio E. Goulart Sant'Ana ${ }^{1 *}$
}

\author{
${ }^{1}$ Instituto de Química e Biotecnologia, Centro de Ciências Exatas e Naturais, Universidade Federal de Alagoas, \\ Cidade Universitária, 57072-970, Maceió, Alagoas, Brasil, \\ ${ }_{2}^{2}$ Instituto de Antibióticos, Centro de Ciências da Saúde, Universidade Federal de Pernambuco, Cidade \\ Universitária, 50740-901, Recife, Pernambuco, Brasil
}

\begin{abstract}
RESUMO: "Atividade antibiótica de algumas plantas medicinais brasileiras". As atividades antibióticas de extratos etanólicos de 16 espécies de plantas usadas em medicina popular no Brasil foram determinadas contra Staphylococcus aureus, Micrococcus flavus, Bacillus cereus, B. subtilis, Salmonella enteretidis, Escherichia coli, Pseudomonas aeruginosa, Proteus mirabilis, Serratia marcescens, Mycobacterium phlei, M. smegmatis e M. fortuitum, contra as leveduras Candida albicans e C. krusei. Entre os trinta e dois extratos testados, somente aqueles derivados de Lafoensia pacari e Pterodon polygalaeflorus mostraram atividade contra as cepas bacterianas e nenhum deles apresentou atividade contra as leveduras. O extrato etanólico das folhas de $L$. pacari mostrou valores de concentração inibitória mínima (CIM) na faixa entre 312,5 a $2500 \mu \mathrm{g}$ / $\mathrm{mL}, 250 \mu \mathrm{g} / \mathrm{mL}, 625 \mu \mathrm{g} / \mathrm{mL}$, e $1250 \mu \mathrm{g} / \mathrm{mL}$, respectivamente, contra oito diferentes variedades de Staphylococcus aureus Gram-positivas, Proteus mirabilis Gram-negativas e os bacilos acidoresistentes Mycobacterium phlei, M. fortuitum e M. smegmatis. O extrato etanólico do caule de L. pacari apresentou valores de CIM de $625 \mu \mathrm{g} / \mathrm{mL}$ contra $S$. aureus. Análise química revelou que os extratos brutos continham taninos, esteróides, fenóis, flavonóides, triterpenos e saponinas: as atividades foram altas o suficiente para possibilitar o isolamento guiado pelo bioensaio e a identificação futura dos compostos ativos.
\end{abstract}

Unitermos: Lafoensia pacari, Pterodon polygalaeflorus, atividade antibiótica.

\begin{abstract}
The antibiotic activities of the ethanol extracts from 16 species of plants used in Brazilian folk medicine have been determined against Staphylococcus aureus, Micrococcus flavus, Bacillus cereus, B. subtilis, Salmonella enteretidis, Escherichia coli, Pseudomonas aeruginosa, Proteus mirabilis, Serratia marcescens, Mycobacterium phlei, M. smegmatis and M. fortuitum, and the yeasts Candida albicans and C. krusei. Among 32 extracts assayed, only those from Lafoensia pacari and Pterodon polygalaeflorus showed activity against the bacterial strains, and none were active against the yeasts. The ethanolic extract from the leaves of L. pacari showed minimum inhibitory concentration (MIC) values of 312.5 to $2500,250,625$ and $1250 \mu \mathrm{g} / \mathrm{mL}$, respectively, against eight different Gram-positive strains of Staphylococcus aureus, the Gram-negative Proteus mirabilis and the acid-fast bacilli Mycobacterium phlei, M. fortuitum and M. smegmatis. The ethanolic extract from the stem of $L$. pacari showed an MIC value of $625 \mu \mathrm{g} / \mathrm{mL}$ against $S$. aureus. Chemical analysis revealed that the crude extracts contained tannins, steroids, phenols, flavonoids, triterpenes and saponins: the activities were sufficiently high to present the possibility of future identification of the active components by bioassay-guided fractionation and purification.
\end{abstract}

Keywords: Lafoensia pacari, Pterodon polygalaeflorus, antibiotic activity.

\section{INTRODUCTION}

Natural resources have, since antiquity, been extensively exploited for medicinal purposes. Numerous plant materials have been employed in folk medicine in attempts to control diseases as diverse as bronchitis, pneumonia, ulcers and diarrhoea. In many countries around the world the use of medicinal plants still contributes significantly in primary health care. In Brazil, large numbers of plants have been used in the form of crude extracts, infusions or plasters in order to treat common infections (Morais et al., 2005; Vendruscolo et al., 2005; Tôrres et al., 2005). Although there is currently little scientific evidence regarding the efficacy of such treatments, traditional medicine is still widely practiced by people living in the interior of the country. Moreover, phytotherapy is becoming an important economic sector in Brazil, and is increasing in popularity as an alternative form of health care (Macedo; Ferreira 2004ab).

Recently, medicinal plants have become the focus of intense study regarding their conservation and potential pharmacological effects. Indeed, the search for new 
pharmacologically active agents, through the screening of natural sources such as microbial fermentations and plant extracts, has led to the discovery of many clinically useful drugs that now play major roles in the treatment of human diseases (Yue-Zong, 1998; Leitão et al., 2006; Funke; Melzig 2006). However, whilst Brazilian folk medicine is substantial, our knowledge of the pharmacological activities and chemical compositions of plant extracts used therein is lacking and demands enhanced levels of scientific attention from local natural product chemists (Falcão et al., 2005; Barbosa-Filho et al., 2005; BarbosaFilho et al., 2006a; Barbosa-Filho et al., 2006b)

The present paper deals with the screening of plants from Brazilian folk medicine for antimicrobial activity. Only plants with documented uses related to their antimicrobial activities were selected (Table 1). Some of the assayed species are already grown as commercial fruit crops, whilst others are well-known ornamental plants. Many of them have been identified with a number of medicinal uses (Braga, 1953; Corrêa; Penna, 1984), and all can be purchased from healers in local markets.

In our initial screening programme, examples of both Gram-positive and Gram-negative bacteria were chosen for inclusion based on their clinical, pharmaceutical and bromatological importance in infectious diseases (Sant'Ana et al., 2006). However, according to Farnsworth (1966), acid-fast bacilli, yeasts and filamentous fungi should be incorporated into the first screening and, in order partially to fulfill this aim strains of Mycobacterium and of Candida were also included in our assays.

\section{MATERIAL AND METHODS}

\section{Plant materials}

Thirty-two extracts from 16 plant species, representing 16 genera within 12 families, were selected for assay based on available ethnobotanical and chemosystematic information (Table 1). The selected plant species were collected and authenticated by Prof. José Elias de Paula [Universidade de Brasilia (UnB-DF), Brasília-DF, Brasil] and Rosangela P. de Lira Lemos [Instituto do Meio Ambiente do Estado de Alagoas (IMAAL), Maceió-AL, Brasil]. Voucher specimens of all plant species have been deposited in the herbaria at UnB-DF and IMA-AL.

\section{Preparation of plant extracts}

Plant material was separated into its selected parts, air dried, ground to a moderately fine powder, extracted with $95 \%$ ethanol at room temperature $(26 \pm 1$ ${ }^{\circ} \mathrm{C}$ ) for 2 days and filtered. The residue was extracted twice more in a similar manner. Each extract was evaporated to dryness under reduced pressure using a rotary evaporator and stored in labelled, sterile, screw-capped bottles at -20
${ }^{\circ} \mathrm{C}$ until required for assay. The amount of plant material collected for the preparation of the extracts was dependent on its availability at harvesting, but the minimum quantity in each case was $500 \mathrm{~g}$ fresh weight.

\section{Assay of antibiotic activity}

The test microorganisms strains were provided by the Departamento de Antibióticos, Universidade Federal de Pernambuco, Recife, Brasil. Clinical isolates of Staphylococcus aureus (133, 138, 139, 149, 155, 246, 247, 311, 401 and 403), Proteus mirabilis IC 03, Mycobacterium smegmatis M11, M. fortuitum M5, and stock isolates of Micrococcus flavus DAUFPE 323, Bacillus cereus DAUFPE 11, B. subtilis DAUFPE 10, Salmonella enteretidis DAUFPE 415, Escherichia coli DAUFPE 84, Pseudomonas aeruginosa DAUFPE 39, Serratia marcescens DAUFPE 398, and Mycobacterium phlei ATCC11758, were maintained on Mueller-Hinton agar (Cleeland; Grunberg, 1986), whilst Candida albicans DAUFPE 1007 and C. krusei DAUFPE 1002 were maintained on Sabourand agar. In order to produce an appropriate inoculum, an overnight culture (grown at $37{ }^{\circ} \mathrm{C}$ ) of bacteria in Mueller-Hinton broth, or of yeast in Sabourand broth, was standardised to an opacity equivalent to 0.5 on the McFarland scale $\left(10^{8} \mathrm{CFU} / \mathrm{mL}\right)$. The resulting suspension was diluted to yield a cellular concentration of $10^{6} \mathrm{UFC} / \mathrm{mL}$, a sterile swab was dipped into the inoculum and streaked across the surface of the appropriate agar-solidified medium.

Paper disk diffusion bioassay (Bauer et al., 1966)

Dried ethanolic extracts of the plant parts (500 $\mathrm{mg}$ ) were dissolved in $5 \mathrm{~mL}$ of ethanol: water (1:1), and $20 \mu \mathrm{l}$ aliquots were applied to individual paper disks (6 $\mathrm{mm}$ diameter; Whatman $\mathrm{N}^{\circ} 1$ for qualitative analysis). After evaporation of the loading solvent, each disk was placed at the centre of a Petri dish containing sterile Mueller-Hinton agar, previously inoculated with the microorganism, and incubated at $37^{\circ} \mathrm{C}$ for $18 \mathrm{~h}$ (or 72 $\mathrm{h}$ for Mycobacterium and Candida). At the end of the incubation time, the diameter of the microbial growth inhibition halo was measured $(\mathrm{mm})$ using a ruler with a sliding calliper.

Minimal inhibitory concentration (MIC) bioassay (Courvalin et al., 1985)

Dried ethanolic extracts of the plant parts (500 $\mathrm{mg}$ ) were dissolved in $5 \mathrm{ml}$ of ethanol: water (1:1). Tenfold serial dilutions of each extract with ethanol: water were carried out to prepare a series of eight dilutions (each with a concentration exactly 10-fold larger than that required for the bioassay) for each extract. Petri dishes were prepared by mixing one part of each diluted extract with nine parts of Mueller-Hinton agar medium. 
All dishes, including those containing ciprofloxacin (60 $\mu \mathrm{g} / \mathrm{mL}$ ) used as positive control, were inoculated with the test organism by streaking the medium with a calibrated loop $\left(0.05 \mathrm{~mL}\right.$ ). After incubation at $37^{\circ} \mathrm{C}$ for $18 \mathrm{~h}$ (or $72 \mathrm{~h}$ for Mycobacterium), Petri dishes were examined for the presence or absence of growth. The MIC value was considered to be the lowest concentration of sample able to totally inhibit microbial growth. Each assay was performed in duplicate, on separate days. The results shown in Table 2 are mean values of two independent determinations. Prior to the assays, it was verified that the loading solvent [ethanol: water (1:1)] was completely inactive against the test organisms under the assay conditions.

\section{RESULTS AND DISCUSSION}

In a preliminary determination of antimicrobial activity, 32 ethanolic extracts from various plant parts of 17 different species (Table 1) were evaluated. Only extracts from leaves and stems of Lafoensia pacari exhibited activity against the Gram-positive Micrococcus flavus and Staphylococcus aureus, and the Gram-negative Proteus mirabilis. The leaf extract was also active against the acid-fast Mycobacterium fortuitum, M. phlei and $M$. smegmatis (Table 2). Whilst this latter extract produced large inhibition halos $(15-17 \mathrm{~mm})$ with Micrococcus flavus, P. mirabilis and the Mycobacterium spp., zones of inhibition were detected with only 8 of the 10 strains of $S$. aureus assayed, and these halos were smaller (10 - 12 $\mathrm{mm}$ ) and strain dependent. The stem extract produced lower levels of growth inhibition against Gram-positive and Gram-negative bacteria than did the leaf extract.

The largest inhibition of growth of Micrococcus flavus (inhibition halo of $20 \mathrm{~mm}$ ) was produced by the extract from the root bark of $P$. polygalaeflorus. Although the root wood extract from this species was much less active against $M$. flavus (halo: $8 \mathrm{~mm}$ ), it showed some significant activity against the acid-fast bacilli Mycobacterium phlei and M. smegmatis (inhibition zones of 15 and $8 \mathrm{~mm}$, respectively). The stem bark extract from P. polygalaeflorus was also active against M. phlei (Table 2)

None of the tested extracts showed observable activity against $B$. cereus, $B$. subtilis, $S$. enteretidis, E. coli, $P$. aeruginosa and $S$. marcescens, nor against the yeasts C. albicans and $C$. krusei. In general, the small number of extracts that exhibited antibiotic activity against the clinical isolates might be explained by a possible preexistent resistant strains.

In the light of the significant activities determined for leaf and stem extracts of L. pacari, and for the root extract of Pterodon polygalaeflorus, determinations of minimal inhibitory concentrations (MIC) were carried out on these samples (Table 2).

The MIC values for the ethanolic extract from leaves of L. pacari were $250 \mu \mathrm{g} / \mathrm{mL}$ for Proteus mirabilis, within the range of 312.5 to $2500 \mu \mathrm{g} / \mathrm{mL}$ for various strains of Staphylococcus aureus, and within the range of 625 to $1250 \mu \mathrm{g} / \mathrm{mL}$ for the acid-fast bacilli. The ethanolic extract from the stem of $L$. pacari showed MIC values of $625 \mu \mathrm{g} / \mathrm{mL}$ for all strains of $S$. aureus. These values (Table 2 ) are comparable with those determined for many other ethanolic extracts of medicinal plants as Entada abyssinica, Terminalia spinosa, Harrisonia abyssinica, Ximenia caffra, Azadirachta indica and Spilanthes mauritiana that showed MIC values between 130 and $8000 \mu \mathrm{g} / \mathrm{mL}$ against bacteria (Fabry et al., 1998), whilst values ranging $64-1000 \mu \mathrm{g} / \mathrm{mL}$ against bacteria, and $32-128 \mu \mathrm{g} / \mathrm{mL}$ against dermatophytes, were reported for Alstonia macrophylla (Chattopadhyay et al., 2001). A small number of plants show significantly lower MIC values, for example, those for Erythrina senegalensis, Bobgunnia madagascariensis, Walteria lanceolata, Uapaca togoensis, Ximenia americana, Khaya senegalensis, Lannea acida, Cissus populnea and Keetia ispida were in the range $23-94 \mu \mathrm{g} / \mathrm{mL}$ (Koné et al., 2004), and extracts of Quercus infectoria and Punica granatum were highly effective against Escherichia coli (O157:H7) with MIC values of 90 and $190 \mu \mathrm{g} / \mathrm{mL}$, respectively (Voravuthikunchai et al., 2004).

The antibiotic activity observed for $L$. pacari could partly explain the popular use of this plant as an anti-inflammatory agent and in the treatment of gastric ulcer. Within the family Lytraceae, two other species have been verified to possess anti-inflammatory properties, namely, Lawsonia inermis and Heimia salicifolia containing, respectively, the naphthoquinone lawsone and the quinolizidine alkaloid cryogenine as the biologically active components (Kaplan et al., 1967; Watson; Malone, 1977; Ali et al., 1995).

The presence of ellagic acid, gallic acid and catechin in Lafoensia pacari has been previously reported (Solon et al., 2000) from the hydro alcoholic stem bark extract. Likewise, the present extract showed to contain tannins as well as steroids, phenols, flavonoids, triterpenes and saponins.

The results presented by L. pacari are highly favourable compared, by example, with the MIC values of 50 and $200 \mu \mathrm{g} / \mathrm{mL}$, respectively, for the purified flavonoids 5,7,4'-trimethoxiflavone and $200 \mu \mathrm{g} / \mathrm{mL}$ to 5,7,3',4'-tetramethoxiflavone derived from Kaempferia parviflora (Yenjai et al., 2004).

The observed antibiotic activity against $S$. aureus $(32-2000 \mu \mathrm{g} / \mathrm{mL})$ of the leaf extract of Alstonia macrophylla has been attributed to the presence of ursolic acid together with other minor components (Chattopadhyay et al., 2001). The antibiotic activity of the condensed tannins, catechin and epicatechin has been previously demonstrated by Esquinazi et al. (2002). Fogliani at al. (2005) reported the antibiotic activity of the ellagitannins, whilst the activity of the terpenoids compounds is well known (Peres et al., 1997). The antibiotic activity of extracts of $L$. pacari could 
Table 1. Plant materials submitted to the antimicrobial activity assay based on their ethnobotanical uses

\begin{tabular}{|c|c|c|c|c|}
\hline $\begin{array}{l}\text { FAMILY / Species and } \\
\text { voucher reference }\end{array}$ & $\begin{array}{l}\text { City-state of } \\
\text { collection and } \\
\text { date of harvest }\end{array}$ & $\begin{array}{l}\text { Plant part } \\
\text { assayed }\end{array}$ & Ethnobotanical use & Reference \\
\hline $\begin{array}{l}\text { ANACARDIACEAE } \\
\text { Schinus terebinthifolius } \\
\text { Raddi. } \\
\text { JEP } 3643 \text { (UB) } \\
\text { ANNONACEAE }\end{array}$ & $\begin{array}{l}\text { Murici - AL, } \\
12 / 2001\end{array}$ & Stem bark & $\begin{array}{l}\text { Febrifuge; depurative; anti-rheumatic } \\
\text { and anti-ulcer }\end{array}$ & $\begin{array}{l}\text { Braga, 1953; Corrêa; Penna, 1984, } \\
\text { Balbach, 1963; Balbach, 1966, Pereira et } \\
\text { al., } 2005\end{array}$ \\
\hline $\begin{array}{l}\text { Annona crassiflora Mart } \\
\text { JEP } 3369 \text { (UB) }\end{array}$ & $\begin{array}{l}\text { Brasilia - DF } \\
08 / 1999\end{array}$ & $\begin{array}{l}\text { Leaves, stem } \\
\text { bark and stem }\end{array}$ & Anti-diarrhoeal & $\begin{array}{l}\text { Braga, 1953; Corrêa; Penna, 1984, } \\
\text { Martins, 1989; Dos Santos; Sant'Ana, } \\
2001\end{array}$ \\
\hline $\begin{array}{l}\text { Annona muricata L. } \\
8530 \text { - IMA - AL } \\
\text { ARALIACEAE }\end{array}$ & $\begin{array}{l}\text { Maceió - AL. } \\
08 / 2000\end{array}$ & $\begin{array}{l}\text { Leaves, stem } \\
\text { and roots }\end{array}$ & $\begin{array}{l}\text { Anti-parasitic; emetic; anti-rheumatic; } \\
\text { astringent; anti-diarrhoeal }\end{array}$ & $\begin{array}{l}\text { Braga, 1953; Corrêa; Penna, 1984; } \\
\text { Gemtchújnicov, } 1976\end{array}$ \\
\hline $\begin{array}{l}\text { Didymopanax morototoni } \\
\text { (Aubl.) Decne \& } \\
\text { Planchon.JEP } 3634 \text { (UB) } \\
\text { ASTERACEAE }\end{array}$ & $\begin{array}{l}\text { Murici - AL, } \\
07 / 2000\end{array}$ & Stem & Used to treat pain & Corrêa; Penna, 1984 \\
\hline $\begin{array}{l}\text { Senecio jurgensenii Hemls. } \\
\text { JEP } 3564 \text { (UB) } \\
\text { CELASTRACEAE }\end{array}$ & $\begin{array}{l}\text { Eldorado do Sul } \\
- \text { RS, 9/1999 }\end{array}$ & $\begin{array}{l}\text { Leaves and } \\
\text { flowers }\end{array}$ & $\begin{array}{l}\text { In the treatment of malaria, fever and } \\
\text { wound healing }\end{array}$ & Milliken, 1997 \\
\hline $\begin{array}{l}\text { Austroplenckia populnea } \\
\text { (Reissek) Lundell. JEP } 3747 \\
\text { (UB) } \\
\text { CLUSIACEAE }\end{array}$ & $\begin{array}{l}\text { Planaltina - GO, } \\
01 / 2001\end{array}$ & $\begin{array}{l}\text { Stem, roots } \\
\text { bark and roots }\end{array}$ & Anti-tumour; anti-microbial & Corrêa; Penna, 1984 \\
\hline $\begin{array}{l}\text { Rheedia brasiliensis } \\
\text { (Mart.)Planch \& Triana. JEP } \\
1793 \text { (UB) } \\
\text { FABACEAE }\end{array}$ & $\begin{array}{l}\text { March. } \\
\text { Deodoro-AL } \\
08 / 1999\end{array}$ & Stem & $\begin{array}{l}\text { Tonic; anti-ulcer; used for wound } \\
\text { healing and in the preparation of } \\
\text { leather }\end{array}$ & Corrêa; Penna, 1984 \\
\hline $\begin{array}{l}\text { Erythrina mulungu Mart ex. } \\
\text { Benth } \\
\text { JEP } 3605 \text { (UB) }\end{array}$ & $\begin{array}{l}\text { S. J. da Tapera } \\
-\mathrm{AL}, 08 / 2000\end{array}$ & Stem & $\begin{array}{l}\text { Tranquilizer; in the treatment of } \\
\text { bronchitis, inflammations and (locally) } \\
\text { lupus }\end{array}$ & $\begin{array}{l}\text { Corrêa; Penna, 1984; Delorme; Miolla, } \\
1979\end{array}$ \\
\hline $\begin{array}{l}\text { Pterodon polygalaeflorus } \\
\text { Benth. } \\
\text { JEP } 3410 \text { (UB) }\end{array}$ & $\begin{array}{l}\text { Brasilia - DF, } \\
08 / 2000\end{array}$ & $\begin{array}{l}\text { Leaves, stem } \\
\text { bark, root bark, } \\
\text { root wood and } \\
\text { seeds }\end{array}$ & $\begin{array}{l}\text { Anti-rheumatic; in the treatment of } \\
\text { throat infections }\end{array}$ & Corrêa; Penna, 1984; Nunan, 1985 \\
\hline $\begin{array}{l}\text { LYTHRACEAE } \\
\text { Lafoensia pacari A. St. } \\
\text { Hil. } \\
\text { JEP } 3535 \text { (UB) }\end{array}$ & $\begin{array}{l}\text { Brasilia - } \\
\text { DF, 01/1999 }\end{array}$ & $\begin{array}{l}\text { Leaves, } \\
\text { stem bark } \\
\text { and stem }\end{array}$ & $\begin{array}{l}\text { Febrifuge; anti-tumour; tonic; } \\
\text { in the treatment of gastric } \\
\text { ulcer and inflammations }\end{array}$ & $\begin{array}{l}\text { Corrêa; Penna, 1984, Ali et al., 1995; } \\
\text { Lima; Martins, 1996; Sartori; } \\
\text { Martins 1996; Albuquerque et al., } 1996\end{array}$ \\
\hline $\begin{array}{l}\text { SAPINDACEAE } \\
\text { Cupania oblongiflora } \\
\text { Mart. } \\
\text { JED } 3538 \text { (UB) }\end{array}$ & $\begin{array}{l}\text { Matriz de } \\
\text { Camaragibe } \\
-\mathrm{AL}\end{array}$ & $\begin{array}{l}\text { Leaves and } \\
\text { stem }\end{array}$ & $\begin{array}{l}\text { In the treatment of coughs and } \\
\text { whooping cough }\end{array}$ & Corrêa; Penna, 1984 \\
\hline $\begin{array}{l}\text { Serjana lethalis A. St. } \\
\text { Hil. } \\
\text { JEP } 3698 \text { (UB) }\end{array}$ & $\begin{array}{l}\text { 11/1999 } \\
\text { Brasília - } \\
\text { DF, 09/2002 }\end{array}$ & $\begin{array}{l}\text { Leaves and } \\
\text { stem }\end{array}$ & Narcotic & Corrêa; Penna, 1984 \\
\hline $\begin{array}{l}\text { SIMAROUBACEAE } \\
\text { Simarouba amara } \\
\text { Aubl. } \\
\text { JEP } 3640 \text { (UB) } \\
\text { STERCULIACEAE }\end{array}$ & $\begin{array}{l}\text { Itabaiana - } \\
\text { SE, } 09 / 2001\end{array}$ & Stem & Febrifuge; anti-diarrhoeal & Corrêa; Penna, 1984 \\
\hline $\begin{array}{l}\text { Guazuma ulmifolia var. } \\
\text { tomentosa (Kunth) K. } \\
\text { Schum. JEP } 3644 \text { (UB) }\end{array}$ & $\begin{array}{l}\text { NS Socorro } \\
- \text { SE, } \\
09 / 2001\end{array}$ & Stem bark & $\begin{array}{l}\text { Astringent; depurative; in the } \\
\text { treatment of syphilis and skin } \\
\text { disease }\end{array}$ & $\begin{array}{l}\text { Braga, } 1953 \text { Corrêa; Penna, } \\
\text { 1984; Balbach,1963; } \\
\text { Balbach,1966; Milliken, 1997; } \\
\text { Vieira } 1992\end{array}$ \\
\hline $\begin{array}{l}\text { ZINGIBERACEAE } \\
\text { Costus spiralis (Jacq.) } \\
\text { Roscoe. }\end{array}$ & $\begin{array}{l}\text { Maceió - } \\
\mathrm{AL}\end{array}$ & Leaves & $\begin{array}{l}\text { Anti-tumour; diuretic; anti- } \\
\text { syphilitic; tranquilizer; in the } \\
\text { treatment of renal stones }\end{array}$ & $\begin{array}{l}\text { Corrêa; Penna, 1984, } \\
\text { Balbach,1963; Balbach,1966 }\end{array}$ \\
\hline $\begin{array}{l}\text { Renealmia exaltata } \mathrm{L} \text {. } \\
\text { F. }\end{array}$ & $\begin{array}{l}\text { Brasilia - } \\
\text { DF, 07/1994 }\end{array}$ & Leaves & $\begin{array}{l}\text { treatment of renal stones } \\
\text { Anthelmintic; tonic; in the } \\
\text { treatment of stomach ache }\end{array}$ & $\begin{array}{l}\text { Corrêa; Penna, 1984, } \\
\text { Balbach,1963; Balbach,1966 }\end{array}$ \\
\hline
\end{tabular}




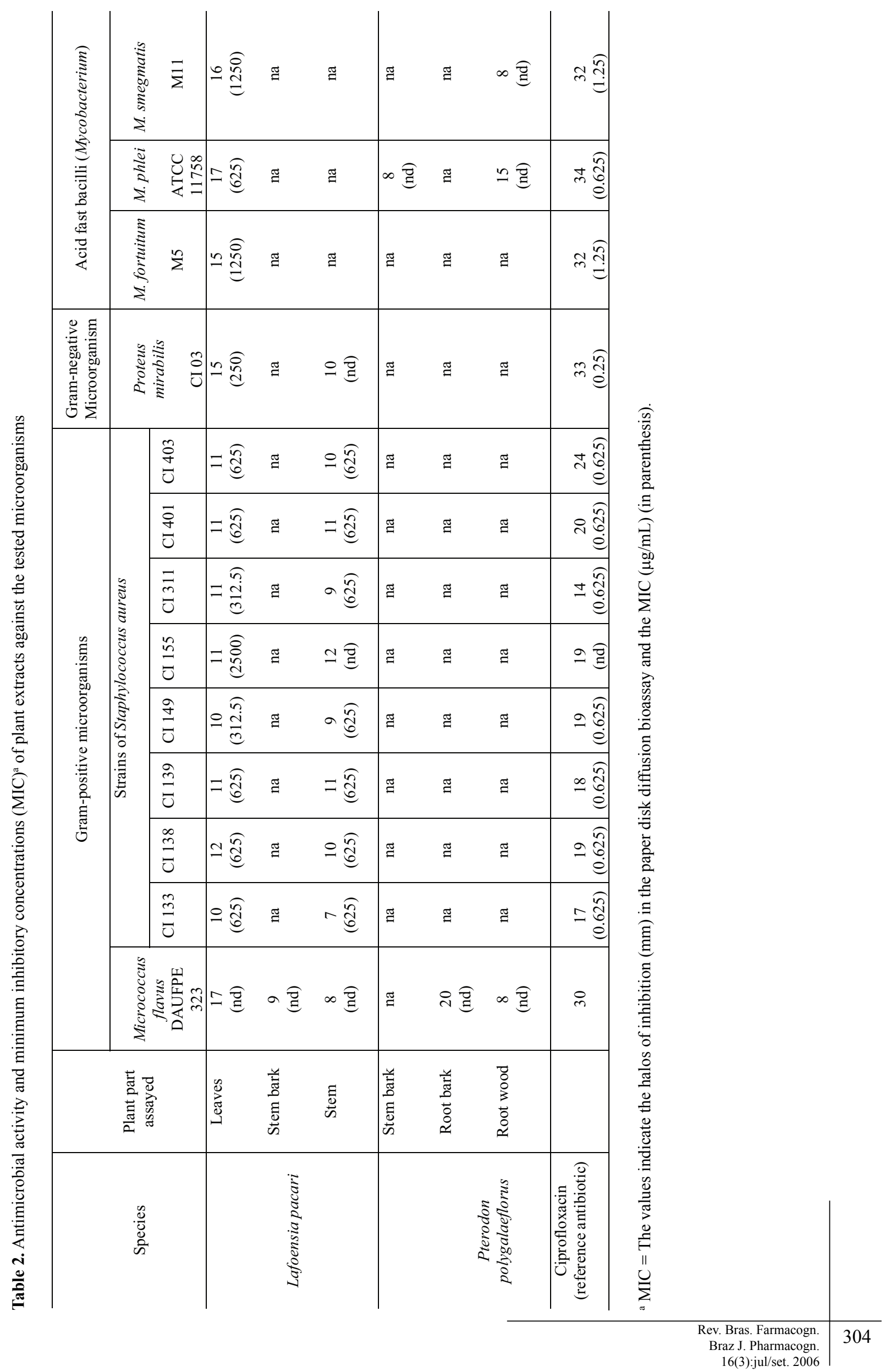


be explained by the presence of tannins (Solon et al., 2000), flavonoids and terpenoids as has been found for P. polygalaeflorus (Fascio et al., 1976; Dos Santos et al., 1972; Mahajan; Monteiro, 1973; Campos et. al., 1994).

The present work has shown that L. pacari is a potential source of antibiotic agents and its activity against various strains of Staphylococcus aureus might be considered sufficient to perform further studies for isolation and identification of the active principles

\section{ACKNOWLEDGMENTS}

This work was financed by the Conselho Nacional de Desenvolvimento Científico e Tecnológico (CNPq, Brasil), Fundação Coordenação de Aperfeiçoamento de Pessoal de Nível Superior CAPES (Brasil) and Fundação de Amparo a Pesquisa do Estado de Alagoas (FAPEAL, Maceió-AL, Brasil).

The authors are grateful to Rosangela P. de Lira Lemos (Instituto do Meio Ambiente do Estado de Alagoas, Maceió-AL, Brasil), Rosário de Fátima de Almeida Rocha (Centro de Ciências Biológicas - Universidade Federal de Alagoas, Maceió-AL, Brasil) and José Elias de Paula (Departamento de Botânica, Universidade de Brasília, Brasília DF, Brasil).

\section{REFERENCES}

Albuquerque DA, Juliani JM, Santos JA, Hosida PY, Borges S, Borralho CT 1996. Efeito do extrato etanólico de Lafoensia pacari sobre peritonite aguda em camundongos. III Reunião Especial da SBPC 'Ecossistemas Costeiros - Do Conhecimento a Gestão', São Paulo.

Ali BH, Bashir AK, Tanira MO 1995. Anti-inflammatory activity, antipyretic, and analgesic effects of Lawsonia inermis L. (Henna) in rats. Pharmacol 51:353-363.

Balbach A 1963. A Flora Nacional na Medicina Doméstica II. São Paulo: A Verdade Presente.

Balbach A 1966. As Plantas Curam. São Paulo: A Verdade Presente.

Barbosa-Filho JM, Vasconcelos THC, Alencar AA, Batista LM, Oliveira RAG, Guedes DN, Falcão HS, Moura MD, Diniz MFFM, Modesto-Filho J. 2005. Plants and their active constituents from South, Central, and North America with hypoglycemic activity. Rev Bras Farmacogn 15: 392-413.

Barbosa-Filho JM, Piuvezam MR, Moura MD, Silva MS, Lima KVB, Cunha EVL, Fechine IM, Takemura OS 2006a. Anti-inflammatory activity of alkaloids: A twenty-century review. Rev Bras Farmacogn 16: 109-139.

Barbosa-Filho JM, Medeiros KCP, Diniz MFFM, Batista LM, Athayde-Filho PF, Silva MS, Cunha EVL, Almeida JRGS, Quintans-Júnior LJ 2006b. Natural products inhibitors of the enzyme acetylcholinesterase. Rev Bras Farmacogn 16: 258-285

Bauer AW, Kireby WMM, Sherris JC, Turc KM 1966. Antibiotic susceptibility testing a standardized single disk method. Am J Clin Path 45: 493-496.

Braga R 1953. Plantas do Nordeste - Especialmente do Ceará Natal: Universitária (UFRN)

Campos AM, Silveira ER, Braz-Filho R, Teixeira TC 1994. Diterpenoids from Pterodon polygalaeflorus. Phytochemistry 36: 403-406.

Chattopadhyay D, Maiti K, Kundu AP, Chakraborty R, Bhadra R, Mandal SC, Mandal AB 2001. Antimicrobial activity of Alstonia macrophylla: A folklore of Bay Islands. J Ethnopharmacol 77: 49-55.

Cleeland R, Grunberg E 1986. Laboratory Evaluation of New Antibiotics in vitro and in Experimental Animal Infection. In: Antibiotics in Laboratory Medicine, Baltimore: Williams and Wilkins.

Corrêa MP, Penna LA 1984. Dicionário das Plantas Úteis do Brasil e das Exóticas Cultivadas. Ministério da Agricultura, Instituto Brasileiro de Desenvolvimento Florestal.

Courvalin P, Goldstein F, Philippon A, Sirot JM 1985. L'Antibiogramme. Bruxelles: MPC/Vigot.

Delorme RJ, Miolla H 1979. Pronto Socorro do Sertão - A Cura pelas Plantas. Porto Alegre Grofosul.

Dos Santos AF, Sant'Ana AEG 2001. Molluscicidal properties of some species of Annona. Phytomedicine 8: 115120.

Dos Santos FD, Vichnewski W, Baker PM, Gilbert B 1972. Prophylaxis of schistosomiasis: diterpenes from Pterodon pubescens Benth. An Acad Bras Cienc 44: 45-49.

Esquenazi D, Wigg MD, Miranda MMFS, Rodrigues HM, Tostes JBF, Rozental S, Da Silva AJR, Alviano CS 2002. Antimicrobial and antiviral activities of polyphenolics from Cocos nucifera Linn. (Palmae) husk fiber extract. Res Microbiol 153: 647-652.

Fabry W, Okemo PO, Ansorg R 1998. Antibactericidal activity of East African medicinal plants. J Ethnopharmacol 60: 79-84.

Falcão HS, Lima IO, Santos VL, Dantas HF, Diniz MFFM, Barbosa-Filho JM, Batista LM 2005. Review of the plants with anti-inflammatory activity studied in Brazil. Rev Bras Farmacogn 15: 381-391.

Farnsworth NR 1966. Biological and phytochemical screening of plants. J Pharm Sci 55: 225-276.

Fascio M, Mors WB, Gilbert B, Mahajan JR, Monteiro MB, Dos Santos Filho D, Vichnewski W 1976. Diterpenoid furans from Pterodon species. Phytochemistry 15: 201-203.

Fogliani B, Raharivelomanana P, Bianchini JP, BouraimaMadjèbi S, Hnawia E 2005. Bioactive ellagitannins from Cunonia macrophylla, an endemic Cunoniaceae from New Caledonia. Phytochemistry 66: 241-247.

Funke I, Melzig MF 2006. Traditionally usad plants in diabetes therapy - phytotherapeutics as inhibitors of $\alpha$ amylase activity. Rev Bras Farmacogn 16: 1-5.

Gemtchújnicov ID 1976. Manual de Taxonomia Vegetal - Plantas de Interesse Econômico Agrícola, Ornamental e Medicinal. São Paulo: Agronomia Ceres.

Kaplan HR, Wolke RE, Malone MH 1967. Anti-inflammatory evaluation of cryogene. J Pharm Sci 56: 13851392.

Koné WM, Atindehou KK, Terreaux C, Hostettmann K, 
Traoré D, Dosso M 2004. Traditional medicine in north Côte-d'Ivoire: Screening of 50 plants for antibacterial activity. J Ethnopharmacol 93: 43-49.

Leitão SG, Castro O, Fonseca EM, Julião LS, Tavares ES, Leo RRT, Vieira RC, Oliveira DR, Leitão GG, Martino V, Sulsen V, Barbosa YAG, Pinheiro DPG, Silva PEA, Teixeira DF, Lourenço MCS 2006. Screening of Central and South American plant extracts for antimycobacterial activity by the Alamar Blue test. Rev Bras Farmacogn 16: 6-11.

Lima GS, Martins OT 1996. Screening farmacológico de plantas medicinais utilizadas popularmente como antiinflamatória. XIV Simpósio de Plantas Medicinais do Brasil, Florianópolis F-035.

Macedo M, Ferreira AR 2004a. Plantas medicinais usadas para tratamentos dermatológicos, em comunidades da Bacia do Alto Paraguai, Mato Grosso. Rev Bras Farmacogn 14(Supl. 1): 40-44.

Macedo M, Ferreira AR 2004b. Plantas hipoglicemiantes utilizadas por comunidades tradicionais na Bacia do Alto Paraguai e Vale do Guaporé, Mato GrossoBrasil. Rev Bras Farmacogn 14(Supl. 1): 45-47.

Mahajan JR, Monteiro MB 1973. New diterpenoids from Pterodon emarginatus Vog. $J$ Chem Soc-Perkin Trans 1: 520-525.

Martins JEC 1989. Plantas Medicinais de Uso na Amazônia. Belém Graficentro/CEJUP.

Milliken W 1997. Plants for Malaria, Plants for Fever - Medicinal Species in Latin America - A Bibliographic Survey, The Royal Botanic Gardens: Kew.

Morais SM, Dantas JDP, Silva ARA, Magalhães EF 2005. Plantas medicinais usadas pelos índios Tapebas do Ceará. Rev Bras Farmacogn 15: 169-177.

Nunan EA 1985. Estudo da atividade antiinflamatória de furanoditerpeno isolados do Pterodon poligalaeflorus Benth e de alguns de seus derivados. Belo Horizonte MSc thesis, ICB-Departament of Biochemistry and Immunology, Federal University of Minas Gerais.

Pereira RC, Oliveira MTR, Lemos GCS 2004. Plantas utilizadas como medicinais no município de Campos de Goytacazes-RJ. Rev Bras Farmacogn 14(Supl. 1): 37-40.

Peres MTLP, Delle Monache F, Cruz AB, Pizzolatti MG, Yunes RA 1997. Chemical composition and antimicrobial activity of Croton urucurana Baillon (Euphorbiaceae). J Ethnopharmacol 56: 223-226.

Sant'Ana AEG, Santos AF, Luna JS, Lima MRF, Andrade MCC, Genet J, Marquez B, Neuville L, Moreau N 2006. Anti-bacterial activity of some Brazilian medicinal plants. J Ethnopharmacol 105: 137-147.

Sartori NT, Martins DTO 1996. Screening farmacológico de plantas medicinais utilizadas popularmente como antiulcera em Mato Grosso. XIV Simpósio de Plantas Medicinais do Brasil, Florianópolis F-092.

Solon S, Lopes L, De Souza Junior PT, Schmeda-Hirschmann G 2000. Free radical scavenging activity of Lafoensia pacari. J Ethnopharmacol 72: 173-178.

Tôrres AR, Oliveira RAG, Diniz MFFM, Araújo EC 2005. Estudo sobre o uso de plantas medicinais em crianças hospitalizadas da cidade de João Pessoa: riscos e benefícios. Rev Bras Farmacogn 15: 373380 .
Vendruscolo GS, Rates SMK, Mentz LA 2005. Dados químicos e farmacológicos sobre as plantas utilizadas como medicinais pela comunidade do bairro Ponta Grossa, Porto Alegre, Rio Grande do Sul. Rev Bras Farmacogn 15: 361-372.

Vieira LS 1992. Fitoterapia da Amazônia. Manual da Plantas Medicinais. São Paulo: Agronômica CERES Ltda.

Voravuthikunchai S, Lortheeranuwat A, Jeeju W, Sririrak T, Phongpaicchit S, Supawita T 2004. Effective medicinal plants against enterohaemorrhagic Escherichia coli O157:H7. J Ethnopharmacol 94: 49-54.

Watson WC, Malone MH 1977. Evaluation of immunosupressive potential of cryogenine using developing and established adjuvant arthritis in rats. J Experim Med 162: 60-74.

Yenjai C, Prasanphen K, Daodee K, Wongpanich V, Kittakoop P 2004. Bioactive flavonoids from Kaempferia parviflora. Fitoterapia 75: 89-92.

Yue-Zhong S 1998. Recent natural products based drug development: A pharmaceutical industry perspective. J Nat Prod 61: 1053-1071.

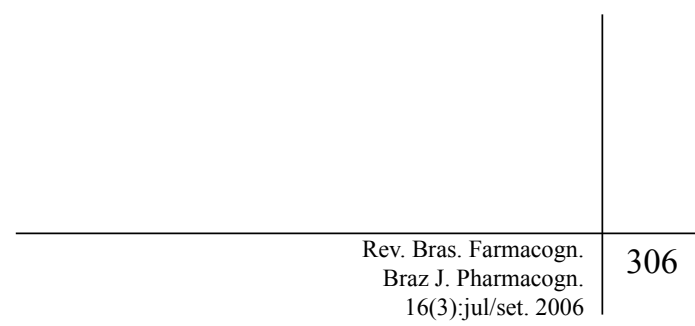

